\title{
Loïc Artiaga, Histoires religieuses francophones et proto-histoire de la culture médiatique
}

\section{Marco Stupazzoni}

\section{Q OpenEdition}

1 Journals

\section{Edizione digitale}

URL: http://journals.openedition.org/studifrancesi/30443

DOI: 10.4000/studifrancesi.30443

ISSN: 2421-5856

\section{Editore}

Rosenberg \& Sellier

\section{Edizione cartacea}

Data di pubblicazione: 1 avril 2006

Paginazione: 171

ISSN: 0039-2944

\section{Notizia bibliografica digitale}

Marco Stupazzoni, «Loïc Artiaga, Histoires religieuses francophones et proto-histoire de la culture médiatique», Studi Francesi [Online], 148 (XLX | I) | 2006, online dal 30 novembre 2016, consultato il 21 avril 2021. URL: http://journals.openedition.org/studifrancesi/30443 ; DOI: https://doi.org/10.4000/ studifrancesi.30443

Questo documento è stato generato automaticamente il 21 avril 2021.

\section{(c)}

Studi Francesi è distribuita con Licenza Creative Commons Attribuzione - Non commerciale - Non opere derivate 4.0 Internazionale. 
Loïc Artiaga, Histoires religieuses francophones et proto-histoire de la culture médiatique

Marco Stupazzoni 


\section{NOTIZIA}

LOÏC ARTIAGA, Histoires religieuses francophones et proto-histoire de la culture médiatique, « Revue d'histoire du XIXe siècle », n² 26-27, 2003, pp. 259-275.

1 A partire dalla prima metà del XIX secolo, l'azione di controllo e di censura intrapresa dal cattolicesimo nei confronti della cultura mediatica francofona assume un rilievo significativo non solo in Francia, ma anche in Belgio e in Canada configurandosi come vero e proprio fenomeno transnazionale.

In questo attento e documentato studio, Loïc Artiaga esamina da diverse prospettive storico-critiche la complessa questione dei rapporti tra «l'Église et la culture médiatique » (p. 261) francofona dell'Ottocento, il cui carattere di « extrême volatilité » e la sua " potentialité à s'affranchir de toute barrière et donc de tout contrôle » (p. 265) scatenarono, fin dai suoi esordi, la ferma reazione della cultura ecclesiastica. L'angoscia e il timore dei cattolici francofoni nei confronti di quelle opere (essenzialmente narrative) viste come nocive alla religione, alla morale e ai buoni costumi si manifesta soprattutto, ma non solo, attraverso il proliferare di testi, di istruzioni pastorali, di manuali di letture, di indici, il cui scopo fu appunto quello di stigmatizzare le diverse forme di questa ondata culturale e di educare la coscienza dei lettori. Tuttavia, accanto a questo necessario «travail de reconnaissance et de bornage de la production, concrétisé par les index et autres guides de lecture, les catholiques s'associent, créent des bibliothèques pour le peuple et exercent des pressions diverses sur le monde de la librairie » (p. 267). 